\title{
SIKAP SISWA TERHADAP PROSES PEMBELAJARAN KITAB SAFINATUNNAJA BAB SALAT HUBUNGANNYA DENGAN PENGAMALAN IBADAH SALAT MEREKA
}

\author{
Undang Burhanudian ${ }^{1)}$, Lilis Halimah ${ }^{2)}$ \\ Jurusan Pendidikan Agama Islam, FTK \\ UIN Sunan Gunung Djati \\ Bandung
}

Email : lilishalimah41@gmail.com

\begin{abstract}
This study aims to analyze and describe the attitudes of students towards the Safinatunnaja Book Learning Process. Data collection techniques were carried out through questionnaires, observation, and documentation. The analytical tool used is the correlational statistical approach, the questionnaire was addressed to 40 respondents as a total sample. From the results of data processing, it can be concluded that (1) The reality of student attitudes towards the learning process of the safinatunnaja chapter of prayer is included in the very positive category (Score 4.4), (2) 3), and (3) The reality of the relationship between the two is (a) the correlation coefficient is in the very high category (0.94); (b) The hypothesis is accepted tcount (16.54) greater than t table (2.02); (c) Meanwhile the level of influence of variable $X$ on variable $Y$ is $65 \%$. This shows that $65 \%$ of the practice of prayer in the madrasa tanwirul qulub is influenced by students' attitudes towards the learning process of the safinatunnaja chapter of the prayer. Thus there are still 35\% more other factors that influence the practice of prayer in the madrasa qulub.
\end{abstract}

Keywords:

Learning Process, Prayer Practice

\begin{abstract}
Abstrak : Penelitian ini bertujuan untuk menganalisis dan mendeskripsikan Sikap Siswa Terhadap Proses Pembelajaran Kitab Safinatunnaja Bab Salat Hubungannya Dengan Pengamalan Ibadah Salat Mereka. Teknik pengumpulan data dilakukan melalui angket, observasi, dan dokumentasi. Alat analisis yang digunakan adalah pendekatan statistik korelasional, penyebaran angket ditujukan kepada 40 orang responden sebagai sampel total. Dari hasil pengolahan data tersebut dapat diambil kesimpulan bahwa (1) Realitas sikap siswa terhadap proses pembelajaran kitab safinatunnaja bab salat termasuk pada kategori sangat positif (Skor 4,4), (2) Realitas pengamalan ibadah salat siswa termasuk pada kategori tinggi (Skor 3,3), dan (3) Realitas hubungan antara keduanya adalah (a) Koefisien korelasinya termasuk kategori sangat tinggi $(0,94)$; (b) Hipotesisnya diterima thitung $(16,54)$ lebih besar dari tabel $(2,02)$; (c) Sementara itu kadar pengaruh variabel $\mathrm{X}$ terhadap variabel $\mathrm{Y}$ sebesar $65 \%$. Hal ini menunjukkan bahwa $65 \%$ pengamalan ibadah salat di madrasah tanwirul qulub dipengaruhi oleh sikap siswa terhadap proses pembelajaran kitab safinatunnaja bab salat. Dengan demikian masih terdapat $35 \%$ lagi faktor lain yang mempengaruhi pengamalan ibadah salat di madrasah tanwirul qulub.
\end{abstract}

Kata Kunci :

Proses Pembelajaran, Pengamalan Ibadah Salat

\section{PENDAHULUAN}

Pendidikan merupakan usaha sadar dan terencana mewujudkan sarana belajar dan proses pembelajaran agar peserta didik secara aktif mengembangkan potensi diri 
kepribadian, kecerdasan, akhlak mulia, serta keterampilan yang diperlukan dirinya, masyarakat, bangsa dan Negara. Hal ini ditegaskan dalam Undang-undang Sistem Pendidikan Nasional Republik Indonesia Nomor 20 tahun 2003, yaitu:

"Pendidikan nasional berfungsi mengembangkan kemampuan dan membentuk watak serta peradaban bangsa, tujuan untuk berkembangnya potensi peserta didik agar menjadi manusia yang beriman dan bertakwa pada Tuhan Yang Maha Esa, berakhlak mulia, sehat, berilmu, cakap, kreatif, mandiri. Warga Negara yang demokratis serta bertanggungjawab.”(Redaksi,2011:7)

Pencapaian tujuan tersebut, lembaga pendidikan formal maupun nonformal mempunyai peranan yang sangat penting dalam menyiapkan siswa yang berkualitas, bertakwa, cerdas dan terampil serta aktif beribadah. Sebagai Islam menghendaki agar manusia di didik supaya ia mampu merealisasikan tujuan hidupnya yang telah digariskan oleh Allah Swt yaitu beribadah hanya kepada Allah. Sebagaimana Firman Allah dalam Q.S. Adz-Dzariat ayat 56 yang berbunyi:

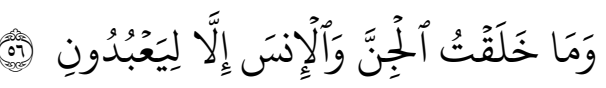

Artinya : "Dan aku tidak menciptakan jin dan manusia melainkan supaya mereka mengabdi kepada-Ku.”.(Q.S Adz-Dzariat: 56)

Berdasarkan ayat diatas, jelas bahwa manusia dalam hidupnya mengemban amanah ibadah, baik hubungan dengan Allah, sesama manusia maupun dengan alam dan lingkungannya. Dan tujuan akhir ibadah yang dilakukan manusia adalah untuk mencapai keridhoan Allah SWT.

Berkaitan dengan pengamalan ibadah salat perlu peneliti uraikan bahwa pengamalan berasal dari kata "amal", yang berarti segala bentuk perbuatan yang dilakukan oleh manusia yang berkonotasi positif. Pengamalan yang dimaksud disini adalah segala perbuatan yang dilakukan oleh siswa dalam menjalankan salat sesuai dengan apa yang telah diajarkan oleh guru di Madrasah. Sedangkan pengertian pengamalan adalah kesungguhan hati dalam melakukan sesuatu.

Adapun pengertian ibadah dalam arti luas adalah segala perbuatan seseorang dengan niat mencari ridho Allah. Sedangkan ibadah dalam arti khusus adalah suatu upacara pengabdian yang sudah digariskan oleh syariat Islam, baik bentuknya serta syarat dan rukunnya seperti salat, zakat, puasa, haji dan sebagainya. (Islam,1985:57)

Beberapa pengertian di atas menunjukkan ibadah merupakan suatu pengabdian seseorang dengan menyerahkan diri sepenuhnya kepada Allah, sesuai dengan ketentuan syariat. Dimana penyerahan diri tersebut semata-mata hanya untuk memperoleh keridhoan dari-Nya.

Adapun salah satu bentuk pengamalan ibadah kepada Allah adalah salat. Salat merupakan ibadah yang paling utama dalam Islam secara mutlak. Bahkan ia merupakan induk dari berbagai ibadah. Karena ibadah selain salat, seperti zakat, puasa, dan haji terkadang kewajibannya gugur atas individu muslim dalam sebagian kondisi 
dikarenakan udzur atau sebab lainnya. Hal itu tidak berlaku dalam ibadah salat, karena salat harus tetap ditegakkan dalam kondisi apapun serta harus mengganti dengan salat pula di lain waktu jika seseorang berhalangan. Kecuali ketika seorang wanita sedang haid, maka tidak perlu mengganti keseluruhan salat yang telah ditinggalkan, akan tetapi mengganti salat yang ditinggalkan pada permulaan dan akhir masa haid sesuai ketentuan.

Selain itu, salat juga merupakan ibadah pertama yang diwajibkan dalam Islam. Kewajiban itu diterima Nabi Muhammad SAW langsung dari Allah SWT ketika peristiwa Isra' dan mi'raj. Salat adalah ibadah pertama yang akan ditanyakan di hari kiamat. Hal ini menandakan bahwa ibadah salat adalah bentuk ibadah khusus yang menjadi salah satu sendi ajaran Islam.

Salat menurut bahasa artinya do'a. Sedangkan menurut istilah, salat adalah ibadah yang tersusun dari beberapa perkataan dan perbuatan yang dimulai dengan takbir dan disudahi dengan salam.(Rasyid, 1997:53) Dalam istilah ilmu fiqih, salat adalah salah satu macam atau bentuk ibadah yang diwujudkan dalam melakukan perbuatan-perbuatan tertentu disertai dengan ucapan-ucapan tertentu dan syarat-syarat tertentu pula.

Berdasarkan pendapat tersebut diatas, maka dapat diambil kesimpulan bahwa ibadah salat adalah suatu bukti ketaatan menjalankan perintah Allah dalam bentuk ucapan dan perbuatan tertentu yang dimulai dari takbir dan diakhiri dengan salam berdasarkan syarat dan rukun yang telah ditentukan.(Agama/IAIN, 1982:76)

Sehubungan pendidikan agama Islam sangat penting, maka sesuai dengan yang terdapat di dalam kurikulum PAI 2004 sebagaimana telah dikutip oleh Ramayulis (Ramayulis, 2005:21) disebutkan bahwa:

Pendidikan agama Islam adalah : Upaya sadar dan terencana dalam menyiapkan peserta didik untuk mengenal, memahami, menghayati, mengimani, bertakwa, berakhlak mulia, mengamalkan ajaran agama Islam dari sumber utamanya kitab suci al-Quran dan Hadits melalui kegiatan bimbingan pengajaran, latihan serta penggunaan pengalaman.

Di dalam pengamalan ibadah salat juga, pasti siswa mendapatkan pembelajaran dari gurunya karena segala sesuatu timbul dari pembelajaran dan pendidikan sehingga siswa dapat mengamalkannya. Dalam hal ini peneliti akan memaparkan mengenai proses pembelajaran kitab safinatunnaja di madrasah.

Pada proses pembelajaran, guru dan siswa merupakan dua komponen yang tidak bisa dipisahkan. Antara dua komponen tersebut harus terjalin interaksi yang saling menunjang agar hasil belajar siswa dapat tercapai secara optimal. Biasanya jam pelajaran di Madrasah mengambil waktu sore hari, mulai ba'da ashar hingga magrhib. Atau, memulai ba'da isya hingga sekitar jam sembilan malam. Lembaga pendidikan Islam ini tidak terlalu perhatian pada hal yang bersifat formal, tetapi lebih mengedepankan pada isi atau substansi pendidikan. (Imam Suprayogo,2010)

Madrasah Diniyah merupakan lembaga pendidikan yang terfokus pada pendidikan Agama. Dengan adanya lembaga pendidikan non formal ini anak-anak desa berhasil mampu membaca al-Quran biasanya melalui lembaga pendidikan seperti ini 
para santri diajari mulai mengenal huruf arab, belajar tajwid, nahwu dan shorof. Selain sebagai lembaga pendidikan yang mengajarkan agama, ternyata keberadaan Madrasah Diniyah juga mempunyai peran yang sangat signifikan dalam mengurangi jumlah angka buta aksara. Bukan hanya bagaimana belajar membaca al-Quran tetapi juga diajarakan bagaimana cara membaca tulisan latin dengan baik.

Berdasarkan hasil observasi bahwasannya di Madrasah Diniyah Tanwirul Qulub banyak siswa yang mengikuti pembelajaran mengenai materi-materi ketentuan menunaikan salat yang utama secara optimal namun mereka menunaikan ibadah salat pun belum terimplementasikan dengan baik seperti halnya masih ada siswa yang salat berjama'ahnya sering kesiangan, bahkan tidak berjama'ah sama sekali. Semestinya, jika mereka sudah mengikuti pembelajaran secara optimal mereka akan menunaikan ibadah salat pun secara optimal.

Sejalan dengan permasalahan di atas, tujuan penelitian ini adalah untuk mengetahui: Sikap siswa terhadap proses pembelajaran kitab safinatunnaja di Madrasah Diniyah Tanwirul Qulub; Pengamalan ibadah salat siswa Madrasah Diniyah Tanwirul Qulub ; dan Hubungan antara sikap siwa terhadap proses pembelajaran kitab safinatunnaja di Madrasah Diniyah Tanwirul Qulub dengan pengamalan ibadah salat mereka.

Secara teoritis manfaat penelitian ini akan mengkaji proses pembelajaran kitab safinatunnaja hubungannya dengan pengamalan ibadah salat. Dengan demikian penelitian ini akan memberikan kontribusi berarti (sumbangan pemikiran) bagi usaha peningkatan proses pembelajaran kitab safinatunnaja bab salat serta pengamalan ibadah salat di Madrasah Diniyah Tanwirul Qulub. sedangkan, manfaat praktisnya terbagi menjadi tiga: Pertama, Bagi Siswa dari penelitian ini siswa dapat memperoleh masukan dalam pengamalan ibadah salat sehingga siswa menjadi lebih maksimal dalam pengamalan ibadah salatnya; Kedua,Bagi Guru informasi penelitian ini diharapkan dapat menjadi informasi serta masukan berharga bagi guru dalam proses pembelajaran kitab safinatunnja bab salat agar dalam proses pembelajarannya lebih optimal lagi; dan Ketiga,Bagi Sekolah hasil penelitian ini diharapkan dapat menjadi informasi berharga bagi kepala madrasah untuk mengambil suatu kebijakan yang paling tepat dalam kaitan dengan upaya menyajikan pembelajaran yang efektik dan efisien.

Hal ini hampir sejalan dengan penelitian yang telah diteliti oleh E. Nurlaela, jurusan Pendidikan Agama Islam Fakultas Tarbiyah dan Keguruan UIN Sunan Gunung Djati Bandung tahun 2009. Dengan judul "SIKAP REMAJA TERHADAP KEGIATAN PENGAJIAN BULANAN HUBUNGANNYA DENGAN PENGAMALAN IBADAH SALAT MEREKA". Hasil penelitiannya ini menunjukkan bahwa bahwa terdapat hubungan yang signifikan. Hal ini terbukti dari analisis korelasi sebesar 0,61 dengan kualifikasi tinggi, karena berada pada interval 0,60-0,79. Begitu juga hasil analisis uji signifikan menunjukkan bahwa t hitung lebih besar dari t tabel yaitu 6,98>1,674. Sementara itu kadar pengaruh variabel $\mathrm{X}$ terhadap variabel $\mathrm{Y}$ sebesar $21 \%$. Hal ini menunjukkan bahwa $21 \%$ pengamalan ibadah salat remaja di pengaruhi oleh sikap 
remaja dalam mengikuti kegiatan pengajian bulanan. Dengan demikian masih terdapat $79 \%$ lagi faktor lain yang mempengaruhi pengamalan ibadah salat mereka.

Menurut Rooijakkers (1991:114) Proses pembelajaran merupakan suatu kegiatan belajar mengajar menyangkut kegiatan tenaga pendidik, kegiatan peserta didik, pola dan proses interaksi tenaga pendidik dan peserta didik dan sumber belajar dalam suatu lingkungan belajar dalam kerangka keterlaksanaan program pendidikan. Pendapat yang hampir sama dikemukakan oleh Winkel (1991:200) Proses pembelajaran adalah suatu aktivitas psikis atau mental yang berlangsung dalam interaksi aktif dalam lingkungan, yang menghasilkan perubahan-perubahan pengetahuan, pemahaman, keterampilan dan nilai sikap.

Beberapa pendapat tersebut dapat disimpulkan bahwa proses pembelajaran adalah segala upaya bersama antara guru dan siswa untuk berbagi dan mengolah informasi, dengan harapan pengetahuan yang diberikan bermanfaat dalam diri siswa dan menjadi landasan berlajar yang berkelanjutan, serta diharapkan adanya perubahanperubahan yang lebih baik untuk mencapai suatu peningkatan yang positif yang ditandai dengan perubahan tingkah laku individu demi terciptanya proses belajar mengajar yang efektif dan efisien. Sebuah proses pembelajaran yang baik akan membentuk kemampuan intelektual, berfikir kritis dan munculnya kreatifitas serta perubahan perilaku atau pribadi seseorang berdasarkan praktik dan pengalaman tertentu.

Proses pembelajaran adalah sebuah upaya bersama antara guru dan siswa untuk berbagi dan mengolah informasi dengan tujuan agar pengetahuan yang terbentuk "terinternalisasi" dalam diri peserta pembelajaran dan menjadi landasan belajar secara mandiri dan berkelanjutan. Maka kriteria keberhasilan sebuah proses pembelajaran adalah munculnya kemampuan belajar berkelanjutan secara mandiri.(Jamaludin, 2015:88) Jadi di dalam proses pembelajaran, guru dan siswa merupakan dua komponen yang tidak bisa dipisahkan. Antara dua komponen tersebut harus terjalin interaksi yang saling menunjang agar hasil belajar siswa dapat tercapai secara optimal.

Tujuan pembelajaran sebenarnya adalah untuk memperoleh pengetahuan dengan suatu cara yang dapat melatih kemampuan intelektual para siswa dan merangsang keingintahuan serta memotivasi kemampuan mereka (Dahar,1996). Tujuan pembelajaran dibagi menjadi tiga kategori yaitu: kognitif (kemampuan intelektual), afektif (perkembangan moral), dan psikomotorik (keterampilan). Hal ini diperkuat oleh pendapat Bloom yang membagi tiga kategori dalam tujuan pembelajaran yaitu: 1) kognitif, 2) Afektif, 3) Psikomotorik (Nasution,1998). Adapun tahapan dalam pembelajaran yaitu: 1) Kegiatan awal : Kata pembuka, Tes awal,Informasi materi; 2) Kegiatan inti: Menyampaikan materi, Tanya jawab, Ringkasan; 3) Kegiatan akhir: Tes akhir, Tanya jawab,Kata penutup.

Kitab safinah memiliki nama lengkap "Sfinatunnaja Yajibu 'ala Abdi li Maulah" (perahu keselamatan di dalam mempelajari kewajiban seorang hamba kepada Tuhanya). Di setiap kampung, kota dan Negara hampir semua orang mempelajari dan bahkan menghafalkannya, baik secara individu maupun kolektif. Kitab ini mencakup 
pokok-pokok agama secara terpadu, disajikan dengan bahasa yang mudah, susunan yang ringan dan redaksi yang mudah untuk dipahami serta dihafal, ditulis oleh seorang ulama yang terkemuka dalam berbagai bidang ilmu keagamaan, terutama fiqih dan tasawuf, dan kitab ini menjadi acuan para ulama dalam memberikan pengetahuan dasar agama bagi para pemula.

Pengamalan adalah dari kata amal, yang berarti perbuatan, pekerjaan, segala sesuatu yang dikerjakan dengan maksud berbuat kebaikan. Sedangkan pengertian ibadah menurut Hasby Ash Shiddieqy yaitu segala taat yang dikerjakan untuk mencapai keridhaan Allah dan mengaharap pahala-Nya di akhirat.(Shiddieqy, 2000:5) Menurut kamus istilah fiqih, ibadah yaitu memperhambakan diri kepada Allah dengan taat melaksanakan segala perintahnya dan anjurannya, serta mematuhi segala larangan-Nya karena Allah semata, baik dalam bentuk kepercayaan, perkataan maupun perbuatan. Orang beribadah berusaha melengkapi dirinya dengan perasaan cinta, tunduk dan patuh kepada Allah SWT.(et.el, 1995:109) Secara bahasa kata salat terambil dari kata الصََّّاكَّ yang artinya do'a, sedang menurut istilah adalah suatu sistem ibadah yang tersusun dari beberapa perkataan dan laku perbuatan, dimulai dari takbir dan diakhiri dengan salam, berdasarkan atas syarat-syarat dan rukun-rukun tertentu.(Razak, 1995:178)

Pengertian yang lebih lengkap dikemukakan Hasbi Ash-Shiddieqy, menurut hasbi hakekat ibadah salat ialah menghadapkan jiwa dan hati seseorang kepada Allah SWT. Yang mendatangkan rasa takut dan patuh (taqwa) kepada kebesaran dan kekuasan-Nya dengan penuh khusu' dan ikhlas, dalam bentuk perkataan dan perbuatan (gerakan) yang dimulai dengan takbir dan diakhiri dengan salam menurut syarat-syarat tertentu.(Ash-Shiddieqy, 1997:64) Pengamalan ibadah salat merupakan perintah yang harus dikerjakan bagi setiap muslim, termasuk didalamnya siswa. Untuk dapat mengamalkan ibadah salat tentunya berkaitan dengan sejauhmana kesadaran beragama siswa dan bagaimana sikap siswa terhadap ajaran agamanya, seseorang yang dalam menyikapi suatu ajaran dengan sikap tanggap dan menerima, hampir bisa dipastikan dalam pengamalannya akan lebih aktif bersungguh, oleh karena berangkat dari sebuah sikap yang positif. Dan menurut Bimo Walgito (2003:127) pengertian attitude itu dapat diterjemahkan dengan kata sikap terhadap objek tertentu, yang merupakan sikap pandangan dan sikap perasaan tetapi sikap maana disertai oleh kecenderungan bertindak sesuai dengan sikap terhadap objek tadi.

Memperhatikan pendapat diatas, maka jelaslah bahwa sikap akan dapat mempengaruhi pada tingkah laku seseorang. Oleh Karena sikap merupakan organisasi yang tetap dari proses emosi, persepsi atau pengamatan atas suatu aspek dari kehidupan seseorang, maka muncullah respon yang bisa bersifat positif-negatif. Begitu juga sebaliknya jika bersikap negatif tentu ia akan menghindari dari keterlibatan pada objek tersebut. Dengan mengetahui sikap seseorang kita akan dapat menduga bagaimana respon atau tindakan yang diambil oleh seseorang tersebut terhadap suatu masalah yang dihadapkan kepadanya. 
Ada beberapa indikator pelaksanaan/pengamalan ibadah salat yaitu: 1) Ketepatan waktu; 2) Keseringan melaksanakan salat; 3) Kefasihan dalam bacaan salat; 4)Ketertiban dalam salat; 5) Keterhindaran dari perbuatan tercela.

Berdasarkan pengamalan ibadah di atas, seseorang diharapkan mampu memiliki keseimbangan dalam hubungannya dengan Allah (hablumminallah) dan hubungannya dengan sesama manusia (hablumminannas). Hal ini dapat diwujudkan dengan berperilaku baik dan mampu berinteraksi dengan baik terhadap lingkungan atau dengan kata lain memiliki akhlakul karimah serta bertakwa kepada Allah SWT.

\section{METODE PENELITIAN}

Penelitian ini dilakukan dengan menggunakan pendekatan kuantitatif. Adapun yang dimaksud dengan pendekatan kuantitatif adalah jenis data yang dapat diukur atau dihitung secara langsung, yang berupa informasi atau penjelasan yang dinyatakan dalam bilangan atau bentuk angka.(Sugiyono, 2010:15)

Metode yang digunakan adalah metode deskriptif, karena masalah yang diteliti adalah masalah yang akan dicapai dan masih berlangsung saat ini. Menurut Yaya Suryana dan Tedi Priatna (2007:103), "Metode deskriptif adalah metode yang diupayakan untuk mengamati permasalahan secara sistematis dan akurat mengenai fakta-fakta dan objek-objek tertentu".

Pada penelitian kali ini peneliti menggunakan jenis penelitian korelasional (correlational research). Dengan menggunakan pendekatan correlational study. Analisis korelasional digunakan untuk melihat hubunngan antara satu variabel dengan variabel lainnya. Hubungan-hubungan tersebut dinyatakan dengan korelasi, penelitian ini dilaksanakan di Madrasah Diniyah Tanwirul Qulub. Sampel pada penelitian ini dengan jumlah 40 orang.

Teknik pengumpulan data yang digunakan dalam penelitian ini adalah Teknik Angket, Metode Observasi, dan Metode Dokumentasi. Angket adalah cara pengumpulan data dengan mempergunakan pertanyaan-pertanyaan tertulis untuk memperoleh informasi dari responden (B. Sandjaja dan Albertus Heriyanto, 2011:151), angket ini ditujukan kepada siswa/i Madrasah Diniyah Tanwirul Qulub; Menurut Kartono metode observasi adalah pengamatan pencatatan dengan sistematika atas fenomena-fenomena yang diselidiki. Dalam arti luas observasi sebenarnya merupakan pengamatan yang dilakukan baik secara langsung maupun tidak langsung, data yang diperoleh berdasarkan hasil observasi diantaranya yakni untuk mengamati pengamalan ibadah salat siswa dan untuk mengamati hasil pengamalan ibadah salat tersebut yang dilihat dari proses pembelajaran kitab safinatunnaja; Dokumentasi adalah: "Mencari data mengenai hal-hal atau variabel yang berupa catatan transkip buku, surat kabar atau majalah, prasasti, notulen rapat, buku agenda dan lainnya.(Hadi, 1992:158), dalam pendokumentasian ini peneliti mengambil data sejarah berdirinya Madrasah Diniyah Tanwirul Qulub, data jumlah guru dan siswa, data sarana dan prasarana, dan lain sebagainya. Peneliti mendapatkan data tersebut dari kepala Madrasah Diniyah Tanwirul Qulub. Teknik pengumpulan data dengan menggunakan angket disusun dan disebarkan ke semua 
sampel kepada skala likert dengan alternatif jawaban dan setiap jawaban diberi bobot sebagai berikut:

\begin{tabular}{|l|l|}
\hline \multicolumn{1}{|c|}{ Variabel X } & \multicolumn{1}{c|}{ Variabel Y } \\
\hline Sangat Setuju (SS) diberi skor 5 & Sangat Sering (SS) diberi skor 5 \\
\hline Setuju (S) diberi skor 4 & Sering (S) diberi skor 4 \\
\hline Ragu (R) diberi skor 3 & Kadang-kadang (K) diberi skor 3 \\
\hline Tidak Setuju (TS) diberi skor 2 & Jarang (J) diberi skor 2 \\
\hline Sangat Tidak Setuju (STS) diberi skor 1 & Sangat Jarang (SJ) diberi skor 1 \\
\hline
\end{tabular}

\section{HASIL PENELITIAN DAN PEMBAHASAN}

Rekapitulasi Persentase Sikap Siswa Terhadap Proses Pembelajaran Kitab Safinatunnaja Bab Salat Hubungannya Dengan Pengamalan Ibadah Salat Mereka

\begin{tabular}{|c|c|c|c|c|}
\hline No & Indikator & Sub Indikator & Skor & Kategori \\
\hline \multirow[t]{4}{*}{1} & \multirow{4}{*}{$\begin{array}{c}\text { Sikap siswa terhadap } \\
\text { proses pembelajaran kitab } \\
\text { safinatunnaja }\end{array}$} & Kegiatan awal & 4,6 & Sangat positif \\
\hline & & Kegiatan inti & 4,3 & Sangat positif \\
\hline & & Kegiatan akhir & 4,2 & Sangat positif \\
\hline & & Rata-rata & 4,4 & Sangat positif \\
\hline \multirow[t]{6}{*}{2} & \multirow[t]{5}{*}{ Pengamalan ibadah salat } & Ketepatan Waktu & 3,1 & Tinggi \\
\hline & & $\begin{array}{l}\text { Keseringan } \\
\text { Melaksanakan Salat }\end{array}$ & 2,8 & Sedang \\
\hline & & $\begin{array}{l}\text { Kefasihan dalam } \\
\text { Bacaan Salat }\end{array}$ & 3,9 & Tinggi \\
\hline & & $\begin{array}{l}\text { Ketertiban dalam } \\
\text { Gerakan Salat }\end{array}$ & 3,6 & Tinggi \\
\hline & & $\begin{array}{l}\text { Keterhindaran dari } \\
\text { Perbuatan Tercela }\end{array}$ & 3 & Tinggi \\
\hline & & Rata-rata & 3,3 & Tinggi \\
\hline
\end{tabular}

Dari tabel diatas dapat diketahui bahwa rekapitulasi persentase sikap siswa terhadap proses pembelajaran kitab safinatunnaja bab salat hubungannya dengan pengamalan ibadah salat mereka di Madrasah Diniyah Tanwirul Qulub, dapat dilihat dari indikator sikap siswa terhadap proses pembelajaran kitab safinatunnaja yang menyatakan pada kegiatan awal sangat positif dengan skor 4,6; kegiatan inti sangat positif dengan skor 4,3; dan pada kegiatan akhir sangat positif dengan skor 4,2. Dapat dilihat dari persentase yang ada pada indikator sikap siswa terhadap proses pembelajaran kitab safinatunnaja tergolong sangat positif dengan persentase 4,4 , artinya siswa sangat positof dalam menyikapi proses pembelajaran kitab safinatunnaja bab salat. 
Dan pada indikator pengamalan ibadah salat yang menyatakan pada ketepatan waktu tinggi dengan skor 3,1; keseringan melaksanakan salat sedang dengan skor 2,8; kefasihan dalam bacaan salat tinggi dengan skor 3,9; ketertiban dalam gerakan salat tinggi dengan skor 3,6; dan keterhindaran dari perbuatan tercela tinggi dengan skor 3. Dapat dilihat dari persentase yang ada pada indikator pengamalan ibadah salat tergolong tinggi dengan persentase 3,3, artinya pengamalan ibadah salat siswa tinggi. Maka supaya pengamalan ibadah salat siswa optimal, hendaknya semua pengalaman ibadah salat siswa yang sudah baik dipertahankan atau bahkan ditingkatkan menjadi lebih baik dan pengamalan ibadah salat yang belum baik diperbaiki secara bertahap.

\section{SIMPULAN DAN SARAN}

Sebagai penutup dari laporan penelitian, dalam bab v ini akan diuraikan tentang simpulan dan saran-saran, berdasarkan hasil analisis data serta pembahasannya. Uraian tersebut adalah sebagai berikut:

1. Sikap siswa terhadap proses pembelajaran kitab safinatunnaja yang terbagi dalam tiga tahap yaitu kegiatan awal pembelajaran, kegiatan inti pembelajaran dan kegiatan akhir pembelajaran, termasuk dalam kategori sangat positif, berdasarkan skor 4,4 yang berada pada interval 4,5 - 5,5. Jadi dapat disimpulkan bahwa sikap siswa terhadap proses pembelajaran kitab safinatunnaja adalah sangat positif dalam hal lain bahwasannya siswa telah menyikapinya dengan baik.

2. Pengamalan ibadah salat siswa termasuk dalam kategori tinggi, berdasarkan skor 3,3 yang berada pada interval 3,5 - 4,5. Jadi dapat disimpulkan bahwa pengamalan ibadah salat siswa adalah tinggi.

3. Hubungan sikap siswa terhadap proses pembelajaran kitab safinatunnaja dengan pengamalan ibadah salat adalah (a) Koefisien korelasinya termasuk kategori sangat tinggi $(0,94)$; (b) Hipotesisnya diterima berdasarkan thitung $(16,54)>t_{\text {tabel }}(2,02)$, artinya terdapat hubungan yang sangat signifikan antara keduanya. Semakin positif sikap siswa terhadap proses pembelajaran kitab safinatunnaja di Madrasah Diniyah Tanwirul Qulub maka semakin tinggi pula pengamalan ibadah salat mereka; dan (c) kadar pengaruhnya sebesar $65 \%$ artinya masih terdapat $35 \%$ faktor lain yang mempengaruhi pengamalan ibadah salat mereka.

\section{SARAN}

Berdasarkan simpulan diatas, ada beberapa hal yang dapat di perhitugkan untuk dilakukan, yaitu: Sikap siswa terhadap proses pembelajaran kitab safinatunnaja dipandang sebagai unsur yang berkorelasi dengan pengamalan ibadah salat mereka. Maka dari itu guru madrasah hendaklah lebih optimal lagi dalam proses pembelajaran agar pengamalan ibadah salat mereka lebih meningkat, seperti dalam halnya dalam proses pembelajaran hendaklah guru memakai metode yang membuat siswa lebih aktif dan mudah untuk dipahami olehnya. 
Undang Burhanuddin, Lilis Halimah

\section{DAFTAR PUSTAKA}

Achmad Sunarto, S. N. (2011). Himpunan Hadits Shahih Bukhari. Jakarta Timur : Annur Press.

Agama/IAIN, P. P. (1982). Ilmu Fiqih 1. Jakarta: Direktorat Pembinaan Perguruan Tinggi Agama.

Ahmadi, A. (2004). Dasar-dasar Pendidikan Agama Islam . Jakarta : Bumi Aksara.

(2009). Psikologi Sosial. Jakarta : PT RINEKA CIPTA.

AMs, S. (2008). Interaksi dan Motivasi Belajar Mengajar. Jakarta : Rajawali Press.

Bimo Walgito. (2003). Psikologi Sosial (suatu pengantar), Yogyakarta : Andi Offiset Creswell, J. (2015). Riset Pendidikan. Yogyakarta : PUSTAKA PELAJAR.

(1998). Qualitative Inquiry And Research Design Choosing Among Five Traditions. Thousand Oaks: CA.

et.el, M. A. (1995). Kamus Istilah Fiqih. Jakarta: PT Pustaka Firdaus.

Hadi, S. (1992). Statistik Ii. Yogyakarta: Andi Ofset.

Hayati, T. (2014). Pengantar Statistik Pendidikan . Bandung: CV Insani Mandiri .

Imam Suprayogo, M. R. (2010, Mei). "Madrasah Diniyah". Retrieved from http://www.Madrasah \%20Diniyah.htm.

Islam, P. P. (1985). Metodik Khusus Pengajaran Agama Islam . Jakarta : Direktorat Pembinaan Perguruan Tinggi Agama Islam.

Jamaludin. (2015). Pembelajaran Perspektif Islam. Bandung: PT Remaja Rosdakarya. Junanto, S. (2016). Evaluasi Pembelajaran di Madrasah Diniyah . At-tarbawi, 178.

Kebudayaan, D. P. (2010). Kamus Besar Bahasa Indonesia . Jakarta : Balai Pustaka. Muhammad Syazali, N. (2014). Olah dan Data Penelian Pendidikan. Langsung: AURA

Nasihuddin. (2016). Evaluasi Pembelajaran. Bandung: Tresna Bhakti Press.

Nuh, I. H. (2008). Panduan Shalat . Jakarta : Pena Pundi Aksara.

Rahman, A. A. (2013). Psikologi Sosial. Jakarta: Rajawali Pers.

Ramayulis. (2005). Ilmu Pendidikan Islam . Jakarta : Kalam Mulia.

Rasyid, S. (1997). Fiqiih Islam . Bandung: Sinar Baru Algesindo.

Razak, M. (1995). Dienul Islam . Bandung: PT Al-Ma'arif.

(2000). Dienul Islam . Bandung: PT Al-Ma'arif.

Redaksi, T. (2011). Undang-undang Republik Indonesia Nomor 20 Tahun 2003 Tentang Sistem Pendidikan Nasional. Jakarta : Sinar Grafika.

RI, D. A. (2012). Al-Quran dan Terjemahannya. Bekasi: Cipta Bagus Segara.

Sarwono, S. W. (2014). Pengantar Psikologi Umum. Jakarta : Rajawali Pers.

Shiddieqy, H. A. (2000). Kuliah Ibadah. Semarang: PT Pustaka Rizki Putra .

(2000). Pedoman Shalat . Jakarta: Bulan Bintang. 
Slameto. (2003). Belajar dan Faktor-faktor yang Mempengaruhinya . Jakarta : Rineka Cipta

Subana. (2000). Statistik Pendidikan. Bandung: Pustaka Setia.

Sugiyono. (2010). Statistika Pendidikan . Bandung: Alfabeta .

(2013). Metode Penelitian Pendekatan Kuantitatif Kualitatif $R \&$ D. Bandung: Alfabeta

Syarifuddin, A. (2010). Garis-garis Besar Fiqih . Jakarta: Kencana . 